\title{
Assessment of Water Quality and Soil Salinity in the Agricultural Coastal Plain (Ravenna, North Italy)
}

\author{
Livia Vittori Antisari ${ }^{1,2}$, Maria Speranza ${ }^{1}$, Chiara Ferronato ${ }^{2}\left(\mathbb{D}\right.$, Mauro De Feudis ${ }^{1,2, * \mathbb{C}}$, \\ Gilmo Vianello $^{1}$ (D) and Gloria Falsone ${ }^{1,2}$ \\ 1 Department of Agricultural and Food Sciences, Alma Mater Studiorum-University of Bologna, Via Fanin, 40, \\ 40127 Bologna, Italy; livia.vittori@unibo.it (L.V.A.); maria.speranza@unibo.it (M.S.); \\ gilmo.vianello@unibo.it (G.V.); gloria.falsone@unibo.it (G.F.) \\ 2 Centro Sperimentale per lo Studio e l'Analisi del Suolo (CSSAS), Alma Mater Studiorum-University of Bologna, \\ 40127 Bologna, Italy; chiara.ferronato@unibo.it \\ * Correspondence: mauro.defeudis2@unibo.it
}

Received: 20 March 2020; Accepted: 17 April 2020; Published: 20 April 2020

check for updates

\begin{abstract}
To improve knowledge on salt leaching suitability on different soils, in Arenosols and Cambisols croplands in the coastal area of Ravenna (Italy), soil samples were collected in the non-irrigation winter period and irrigation summer period. Concurrently, waters of the canal network were also investigated. Soil samples were analyzed for $\mathrm{pH}$, carbonate, total organic carbon (TOC), particle size distribution, electrical conductivity (EC), bulk density (BD) and water content at field capacity (FC). Water samples were investigated for $\mathrm{pH}, \mathrm{EC}$, biological and chemical oxygen demand, sodium adsorption ratio, phosphorus, nitrogen, sulfates and chlorides. All soils had low TOC concentrations and Arenosols showed the lowest clay content, BD and FC. Soils had similar EC values in winter, but in summer the lowest ones were observed in Arenosols, suggesting that irrigation mitigated salinization in Arenosols, while the high clay content, BD and FC prevented or limited the salt leaching in Cambisols. In summer, the increase of total nitrogen and biological oxygen demand, especially in drainage channels, might suggest the leaching of soluble nutrients and organic matter from soils due to the high irrigation water volumes. Finally, our findings stress the need to consider soil type and properties to contrast soil salinization without negative effects on soil $\mathrm{C}$ leaching caused by salt leaching practice.
\end{abstract}

Keywords: soil degradation; salinity; water management; soil salt leaching; kriging analysis

\section{Introduction}

Soil salinization is a major threat for land degradation, having an impact on a number of soil functions, in particular, a direct negative effect on soil biology and organic matter dynamics, and an indirect effect leading to loss of soil stability through changes in soil structure [1]. According to the Food and Agriculture Organization (FAO), around 950 Mha of the world's land is affected by soil salinization [2]. In Europe, soil salinity affects about 3.8 Mha of land [3] and the largest part is concentrated in the coastal areas of Southern Europe [1], suggesting high susceptibility of coastal areas to soil salinization. In coastal areas, in fact, the rise of sea level causes salt intrusion and the increase of soil salinization risk. This risk can be further stressed by the human activities. For instance, sodic and saline soils can be due to mismanagement of irrigation that, at present, affects 34 Mha, namely more than $10 \%$ of the irrigated lands [1]. In coastal areas, groundwater overexploitation is another important issue causing the acceleration of seawater intrusion and, consequently, the enhancement of soil salinization $[4,5]$. 
An excess of irrigation water is often used in these areas to prevent or mitigate soil salinization, acting as an important factor for soil washing and for counteracting the saline groundwater rise [6]. It is well known that water and soil quality are strictly related, and that soil degradation is prevented by keeping minimum threshold values for salinity (determining the electrical conductivity of the water, EC) and sodicity (determined by sodium adsorption ratio, SAR) in irrigation water [7]. Application of excess water for leaching purposes, above that needed for meeting evapotranspiration needs, thus places on the one hand a high demand on water resources, and on the other, increases the salt and nutrient load of the drainage water. The practice of soil salt leaching through abundant irrigation must be thus managed with both availability of irrigation water of good quality and the leaching of nutrients and water-soluble organic substances from soil [8]. Measures to assure water of good quality (i.e., low salinity and sodicity) and to restore soil fertility are necessary in order to avoid further soil degradation.

Leaching requirements are, however, usually calculated by considering evapotranspiration demand and crops needs, but seldom defined according to soil characteristics, e.g., [9]. This occurs even if it is well known that soil properties can impede leaching, thus preventing salt washing $[10,11]$. More information on local pedological features can increase the effectiveness of salt leaching and the preservation of soil and water resources.

The coastal plain near Ravenna (Northern Italy) was reclaimed in the last century for agricultural purposes and agriculture is presently one of the main land uses. The area is strictly regulated by an artificial network of canals and furrows that serve for both irrigation and drainage purposes. Furthermore, due to the vicinity to the coast, saline intrusion affects the quality of both surface water and groundwater, and consequently the soil salinization risk increases. Seawater intrusion along the rivers, canals and the groundwater aquifer is exacerbated by subsidence [12,13], causing progressive freshwater deterioration, which represents one of the principal threats of the area [14]. As far as the current irrigation practices in the area are concerned, the water used exceeds the crop requirements, promoting the leaching of salts from soil. Additionally, a certain pedovariability occurs in this area [15], and therefore it is a good model for testing the response of different soil types to salt leaching.

This work aimed to evaluate the following characteristics of the study area: (i) the soil type and water quality, (ii) the spatial distribution of soil and water salinity, and (iii) the seasonal evolution of soil and water salinity, which are used to assess the suitability of the current management practices for controlling soil salinization in this area and the risk of land degradation due to soil type-irrigation water interaction. We hypothesize that spatial and seasonal variability in water and soil quality should occur due to the type and physicochemical properties of soils, and their interactions with water management and saline water dynamics.

\section{Materials and Methods}

\subsection{Study Area}

The study area is in the Ravenna Municipality and was reclaimed between the end of the IXX century and the beginning of the XX century. For the hydraulic safety of the territories, the area is characterized by a dense network of drainage ditches and canals [16], which are under the management of the Western Romagna Land Reclamation Consortium. The main tasks of the consortium are to regulate water in the canal network, supply water to the countryside through irrigation and to contribute to the protection of the territory and the environment in general [17]. The study area is flat and extends from the Reno River in the north and the Lamone River in the south (Figure 1), and experiences a mean annual precipitation and temperature of $638 \mathrm{~mm}$ and $13.3^{\circ} \mathrm{C}$, respectively. The area includes about $30 \mathrm{~km}^{2}$ of intensive agricultural land, mainly on fine texture soils, as well as natural and seminatural areas (ancient pinewoods with Pinus pinea and Quercus ilex, and recent reforestation pinewoods with Pinus pinaster, both on sandy soils, and mesoigrophilous woods with Populus alba, Salix alba, Quercus robur on freshwater and brackish wetlands, and brackish flooded 
meadows) belonging to the European ecological network, Natura 2000. Each farm plans its crops year by year, establishing an annual rotation of the different crops. Crops cultivated in the study area include winter cereals (wheat, barley) sown in October and harvested at the end of June, summer crops such as corn, sorghum, sunflowers, onion and soybean, sown in spring and harvested in summer/autumn, and perennial alfalfa. Since precipitation mainly occurs in autumn and winter, the summer crops are irrigated. In particular, as an example, in the present study area, the irrigation volumes range between 2731 and $2790 \mathrm{~m}^{3} \mathrm{ha}^{-1}$ year ${ }^{-1}$ for onion, 2889 and $3904 \mathrm{~m}^{3} \mathrm{ha}^{-1}$ year $^{-1}$ for

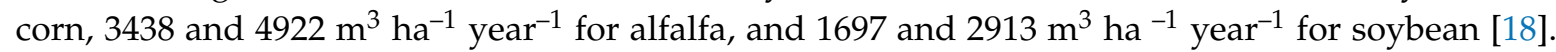
Therefore, the irrigation volume data indicate a daily water requirement of about $16 \mathrm{~m}^{3}$ and water volumes withdrawn from the canals of about $980,000 \mathrm{~m}^{3}$ year $^{-1}$ [18].
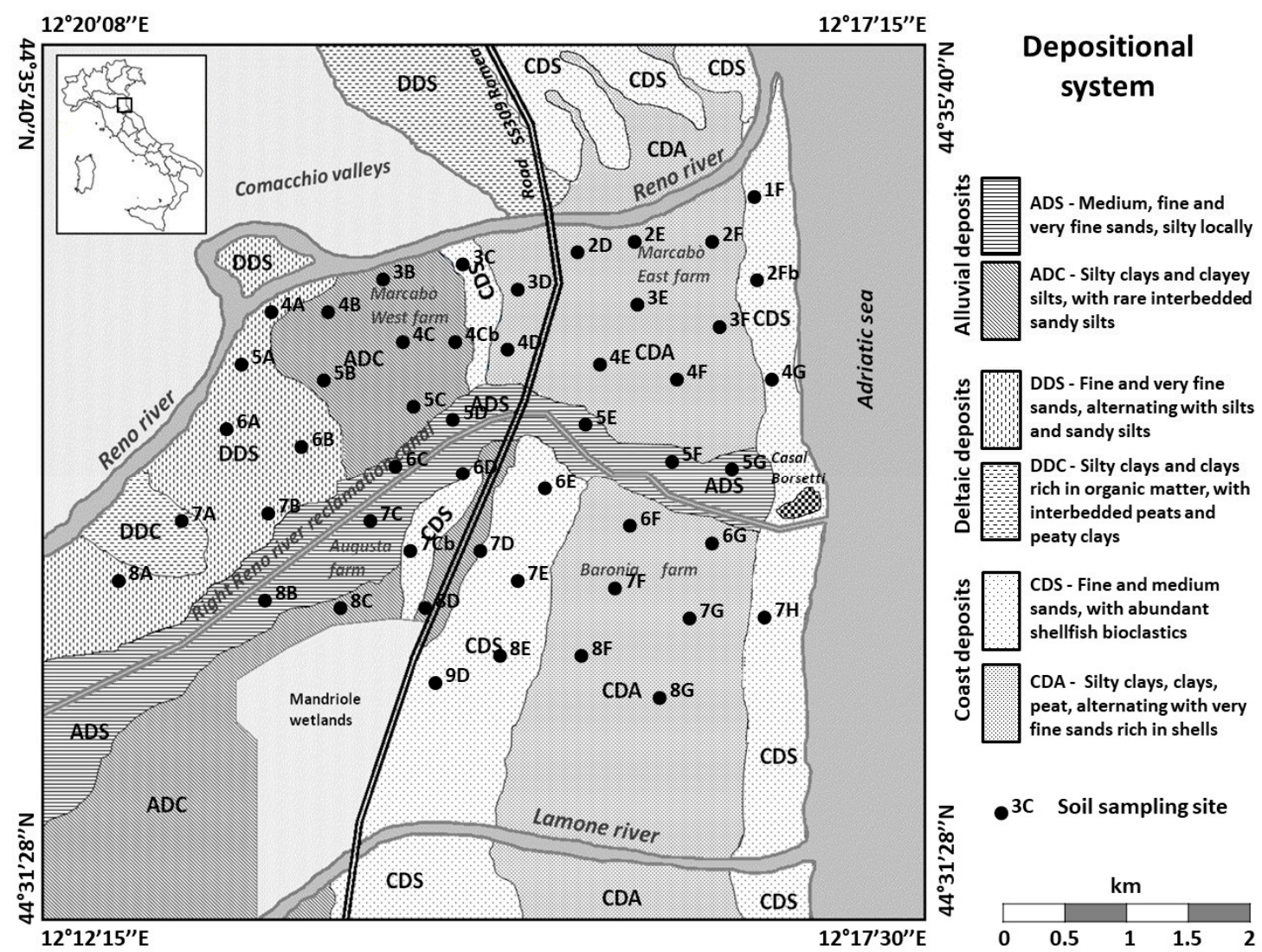

Figure 1. Depositional system of the study area according to ISPRA [19].

In the study area, different sedimentary depositional units occur [19]: alluvial deposits of sand and silt (ADS) and of silty clay and clayey silt (ADC), deltaic deposits of silty sand and silty clay rich in organic matter (DDC), and sandy (CDS) and silty clay (CDA) coastal deposits (Figure 1).

As reported in the soil map (Figure 2), most of the area includes Arenosols and Cambisols, and for a small portion, Fluvisols and Gleysols [20]. Within the soil reference groups, prefix qualifiers are mainly related to the presence of redoximorphing conditions (gleyic), water stagnation (stagnic), salt presence (salic), alternations of alluvial materials (fluvic), vertisolization (vertic) and high saturation bases (eutric), all of which were detected. On the ancient sandy coastal deposits parallel to the coastal line, covered mainly by wetlands and woodland, Eutric Arenosols developed (euAR). In the low land, Stagnic Fluvisols (Siltic) (stFL) developed on the silty sedimentary deposits while Subaquatic Stagnic Gleysols (sq/stGL) occur in the renaturalizing land (e.g., wetlands) with a shallow water table. Cambisols are more ubiquitous and mainly devoted to agriculture. Among them, Fluvic Cambisols (flCM) developed on ADS with silt deposited locally and spread along the Right Reno River canal (CDR), which was built on the ancient Lamone river bed and diverted during the reclamation work. 
Stagnic Cambisols (stCM) and Stagnic (Salic) Cambisols (st(s)CM) are mostly located in the northwest part of the area, on silty clays and clayey silt alluvial deposits (ADC). Both Vertic and Gleyic Cambisols (vrCM and glCM, respectively) were recognized near the Reno River bed on deltaic deposits silty clay and clay-rich organic peat (DDS and DDC, respectively). Finally, Endogleyic Cambisols (glCM and gl(s)CM, respectively), characterized by different salt concentration and, consequently, with salic properties, developed between the two sandy dunes on the coastal deposits, formed by silty clay and clay, and peat layers alternating with very fine sand.

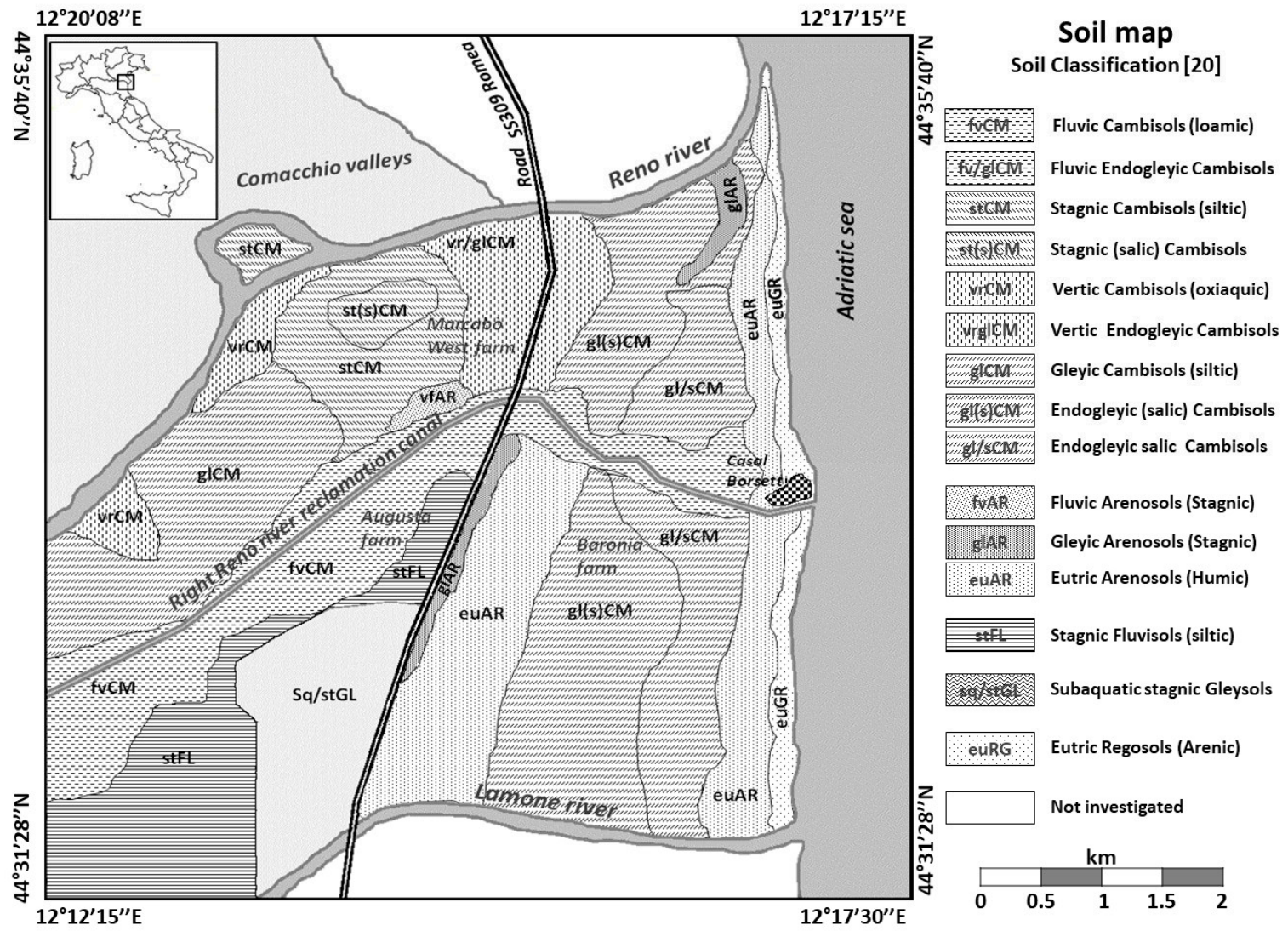

Figure 2. Soil map of the study area.

The water bodies and network of artificial canals in the investigated area were the Reno and Lamone rivers to the north and south side, respectively, and the Right Reno River Reclamation canal (CDR) in the west-east direction (Figure 3).

CDR discharges water by gravity into the Adriatic Sea, and it is dammed on both banks along its whole extension. The network of artificial canals consists of several major and minor canals, discharged mechanically into the CDR through a drainage system [21]. These canals are used both for drainage and irrigation purposes. Generally, the irrigation activity, provided for crops with a high demand for water, begins in March/April and ends in September/October. During the irrigation summer period, the derivation of good irrigation water is diverted from the Reno river into the CDR and, consequently, this canal feeds the secondary canal network $[17,22]$. 

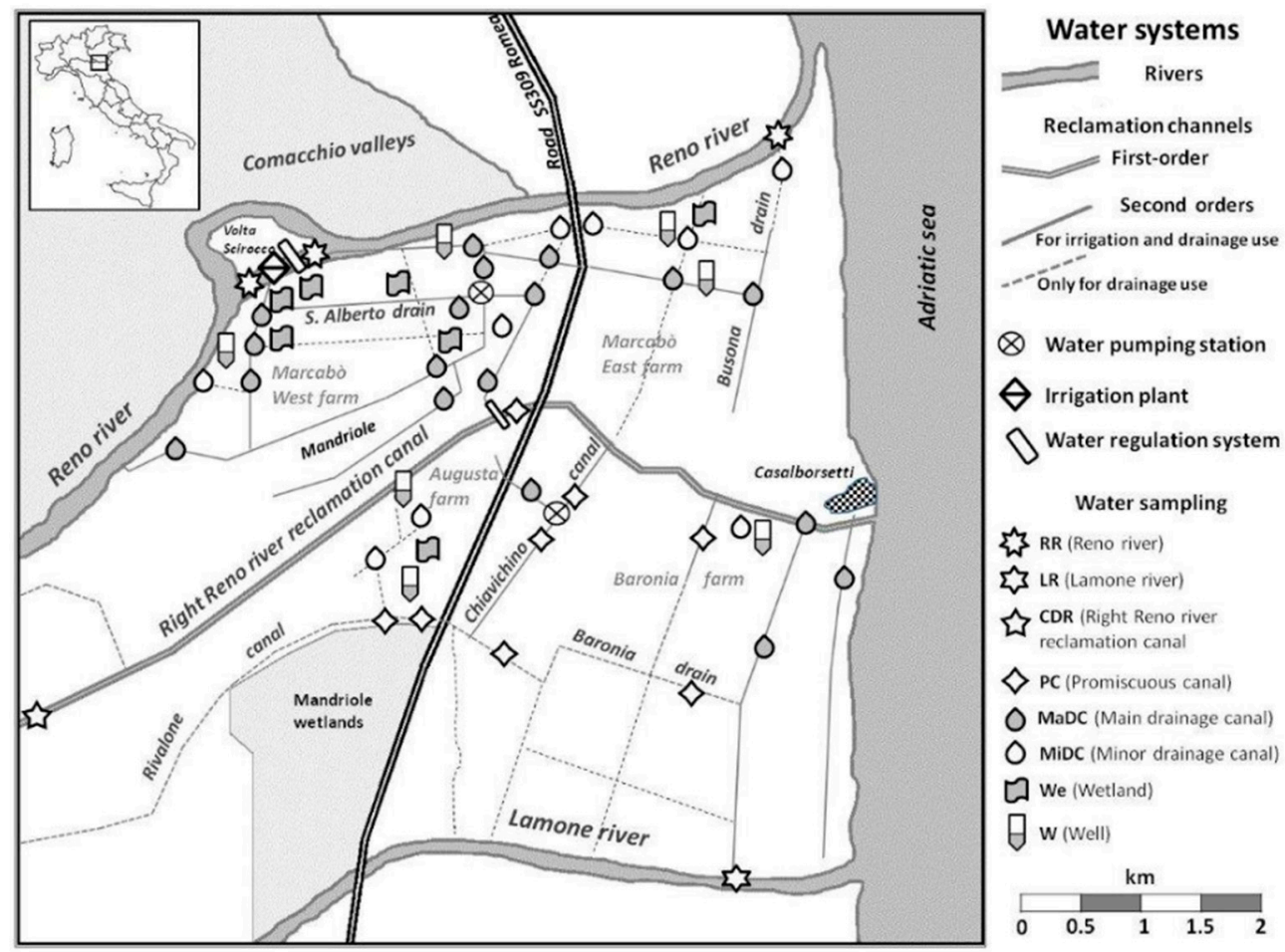

Figure 3. Map of the water bodies and network of artificial canals in the study area (from Cipolla et al. [21]).

\subsection{Soil Sampling}

The soil sampling survey was planned on the basis of the regional soil delineation map [15]. The first soil sampling was carried out in October 2017 through a predetermined grid with cells of about $1 \mathrm{~km}$ on the side, identifying 50 georeferenced points (Figure 2), corresponding to about one sampling point every 60 ha [23]. Specifically, the soil sampling density was carried out as a function of the land unit sizes and subsequent refilling was performed if soil characteristics were observed to change within the same land unit.

These samples, collected within the non-irrigation period, referred to the winter season. In order to evaluate the seasonal variability of soil salinity, a second soil sampling survey at the same sampling points was carried out in July 2018, during the irrigation period, and referred to the summer season. The precipitation in the winter season (non-irrigation period, from September 2017 to February 2018) was higher than the mean (data from 1961 to 2018), and were 90 and $59 \mathrm{~mm}$, respectively; the precipitation in the summer season (irrigation period, from March to August 2018) instead fitted well with the mean, and were 55 and $52 \mathrm{~mm}$ [24].

At each georeferenced point, a hole was drilled at four different fixed depths $(0-10,10-30,30-60$, $60-90 \mathrm{~cm}$ ) [25]. To measure the soil bulk density (BD) values, undisturbed samples of each hole and soil depth were also taken using an Eijkelkamp sampler ring kit, model C, Ø53 mm (Eijkelkamp, Soil \& Water, Giesbeek, The Netherlands).

\subsection{Water Sampling}

During the non-irrigation and irrigation periods, water sampling was performed monthly at fifty-six georeferenced points selected in rivers (RR and LR), the canal network (CDR, MaDC, MiDC and PC), wetlands (WE) and wells (W) (Figure 3 and Table 1). 
Table 1. Brief description and codes of sampled water bodies.

\begin{tabular}{|c|c|c|c|}
\hline Localization/Identification & Water Body Types & Code & Water Sample Code \\
\hline \multirow{2}{*}{ Reno river } & \multirow{2}{*}{ River } & \multirow{2}{*}{$\mathrm{RR}$} & $\begin{array}{l}\text { FW-freshwater samples } \\
\text { from upstream stations }\end{array}$ \\
\hline & & & $\begin{array}{l}F W v \text {-freshwater samples } \\
\text { from downstream stations }\end{array}$ \\
\hline \multirow{2}{*}{ Lamone river } & \multirow{2}{*}{ River } & \multirow{2}{*}{ LR } & $\begin{array}{l}\text { FW-freshwater samples } \\
\text { from upstream stations }\end{array}$ \\
\hline & & & $\begin{array}{l}\mathrm{FWv} \text {-freshwater samples } \\
\text { from downstream stations }\end{array}$ \\
\hline \multirow{2}{*}{ Right Reno River canal } & \multirow{2}{*}{ Reclamation canal } & \multirow{2}{*}{ CDR } & $\begin{array}{l}\text { FW-freshwater samples } \\
\text { from upstream stations }\end{array}$ \\
\hline & & & $\begin{array}{l}\mathrm{FWv} \text {-freshwater samples } \\
\text { from downstream stations }\end{array}$ \\
\hline Main drainage canal & Drainage canal & $\mathrm{MaDC}$ & $\mathrm{MaDC}$ \\
\hline Minor drainage canal & Drainage and irrigation canal & MiDC & MiDC \\
\hline Promiscuous canal & Drainage and irrigation canal & PC & PC \\
\hline Wetland & $\begin{array}{l}\text { Constructed wetland in the } \\
\text { agricultural land }\end{array}$ & WE & WE \\
\hline Well & Well at $3 \mathrm{~m}$ of depth & $\mathrm{W}$ & $\mathrm{W}$ \\
\hline
\end{tabular}

The freshwater samples collected from the upstream and downstream stations of rivers (RR, LR) and reclamation canal (CDR) were coded as FW and FWv, respectively (Table 1).

Water samples were collected within the autumn-winter non-irrigated period, referred to as the winter season, while the samples were also collected during the spring-summer irrigated period, referred to as the summer season. During water sampling, electrical conductivity (EC) and $\mathrm{pH}$ of the water samples were measured by portable instruments (Hanna Instruments). Water samples were then soon transported to the laboratory and kept at $4{ }^{\circ} \mathrm{C}$ for further analysis.

\subsection{Soil Analyses}

Undisturbed soil samples collected in the steel cylinder were water saturated in a water bath and subjected to different sequential phases of drying for the evaluation of the field capacity (FC) and for the permanent wilting point (WP), according to the procedures described by Klute and Klute [26]. Then, the samples were dried at $105^{\circ} \mathrm{C}$, and the bulk density (BD) calculated by dividing the mass of the dried sample by its volume.

The drilling samples were air dried and sieved at $2 \mathrm{~mm}$ before analysis. The soil organic matter was measured by loss of ignition according to Schulte and Hopkins [27] and Cambardella et al. [28], and the total organic carbon (TOC) was calculated using a 1.72 correlation factor [29-31].

The total carbonate content $\left(\mathrm{CaCO}_{3}\right)$ was volumetrically determined [32]. The particle size distribution (sand, silt, clay) was carried out using the pipette method [33] after the dispersion of soil particles with sodium hexametaphosphate. Soil reaction $(\mathrm{pH})$ was performed in 1:5 $(w / w)$ aqueous suspension according to the ISO 10390:2005 method and measured with Crison pH meter (Crison Instruments, Barcelona, Spain). Soil electrical conductivity ( $\left.\mathrm{EC}_{1: 5}\right)$ was determined on 1:5 (w/w) aqueous suspension filtered with Whatmann 42 on samples collected both in winter and summer. $\mathrm{EC}_{1: 5}$ values were then reported as $\mathrm{EC}$ on the saturation extract $\left(\mathrm{EC}_{\mathrm{ew}}\right.$ and $\mathrm{EC}_{\mathrm{es}}$ for winter and summer samples, respectively) using the following pedofunctions [15]:

$$
\begin{gathered}
\mathrm{EC}_{\mathrm{e}}=5.159 \cdot \mathrm{EC}_{1: 5} \quad \text { for samples with } \mathrm{EC}_{1: 5}<1.1 \mathrm{dS} \mathrm{m}^{-1} \\
\mathrm{EC}_{\mathrm{e}}=1.561+2.006 \cdot \mathrm{EC}_{1: 5} \quad \text { for samples with } \mathrm{EC}_{1: 5}>1.1 \mathrm{dS} \mathrm{m}^{-1}
\end{gathered}
$$




\subsection{Water Analyses}

In additional to the water parameters measured in the field ( $\mathrm{pH}$ and $\mathrm{EC}$ ), the following water analysis was performed in the laboratory on the collected samples: total water-dissolved nitrogen (TN), detected by L-TOC (Shimazu Instrument, Kyoto, Japan); chemical oxygen demand (COD), biological oxygen demand (BOD) and anions $\left(\mathrm{Cl}^{-}\right.$and $\left.\mathrm{SO}_{4}{ }^{2-}\right)$ were detected with a Hach Lange appropriate kit; total P (TP) content was measured using an inductive coupled plasma-optical emission spectrometer (ICP-OES, Spectro, Argos); sodium absorption ratio (SAR) was determined as $\mathrm{Na}^{+} /\left[\left(\mathrm{Ca}^{2+}+\mathrm{Mg}^{2+}\right) / 2\right]^{0.5}$, where the ion concentrations were measured by ICP-OES (Spectro, Argos).

\subsection{Data Processing}

Soil data processing was performed on the basis of the soil classification, and only the data of the most frequent soil types were processed (i.e., euAr, fvCM, gl(s)CM, glCM, stCM and vr/glCM). Water data analysis was performed on the basis of the type of water body (i.e., FW and FWv, MaDC, MiDC, PC, WE and W). Both for soil and water datasets, we performed two distinct series of analyses, depending on the period (winter or summer) of the field survey.

For soil data elaboration, two different layers were examined: the first, called the superficial layer (SL), was the average of the values obtained by analysis of the 0-10 and 10-30 cm layers, and the second, called the deep layer (DL), as the average of 30-60 and 60-90 cm layers. Normally, in the study area, the soil tillage depth is at $30 \mathrm{~cm}$, thus the grouping of soil samples in SL and DL allowed us to compare the tilled layer to the underlying one.

Analysis of the variance was performed with the nonparametric Kruskal-Wallis test, in order to infer statistical differences in the physicochemical properties among the different water body and soil types.

In order to evaluate the soil and water EC variation in the space, kriging analysis was performed using library (geoR). The trend of dependence between two units with respect to the distance between them is referred to as a variogram. The estimation of the empirical variogram was carried out by setting a maximum distance to consider. The geoR library uses the variofit function for the estimation of the parameters of the model variogram. A range of values was given for the initial parameters, the variofit function then selected the values of the partial sill and the range that give the smallest value of the summation and use them as initial values for the minimization. The kriging analysis was repeated for both the winter and summer datasets in order to understand how the spatial variability of EC changes over time. Localization in space occurs through georeferencing of the different points to predict the value of the variable in space, exploiting the information derived from the spatial correlation structure present in the data. An empirical variogram was estimated and different mathematical models were tried, and the final model, which minimized the sum of the squares, was chosen. The visualization of the result was graphical, creating a map (contour plot) with the estimated trend of residue values in space. In soil EC maps, the information about a soil's classification was also reported. The linear relationship among variables was checked by the Spearman's rank correlation coefficient.

All data elaboration was carried out using R software [34].

\section{Results}

\subsection{Soil Quality in the Agricultural Coastal Plain}

Table 2 shows the physicochemical properties of the investigated superficial and deep soil layers, grouped according to the soil types.

Statistical differences in physicochemical data were found among soil types (Table S1 in Supplementary Materials) but not between superficial and deep layers (data not shown). As expected, the euAR soils (Arenosols) were enriched in sand content $(86.6 \%$ and $89.9 \%$ on average, in superficial and deep layers, respectively), showing the lowest values of $\mathrm{pH}(7.5)$, carbonate $(10.7 \%$ and $11.3 \%)$, 
silt $(8.3 \%$ and $6.6 \%)$, clay $(5.0 \%$ and $3.6 \%)$, BD $\left(1.5 \mathrm{~g} \mathrm{~cm}^{-3}\right)$, organic $\mathrm{C}(0.3 \%)$ and water content at field capacity $(18 \%)$.

Table 2. Mean and standard error (SE) of $\mathrm{pH}$, amounts of total organic $\mathrm{C}(\mathrm{TOC})$, carbonates $\left(\mathrm{CaCO}_{3}\right)$, sand, silt and clay, water content at field capacity (FC), water content of wilting point (WP), bulk density (BD), soil electrical conductivity in the non-irrigation winter period $\left(\mathrm{EC}_{\mathrm{ew}}\right)$ and in the irrigation summer period $\left(\mathrm{EC}_{\mathrm{es}}\right)$ for superficial layers and depth layers of the investigated soils.

\begin{tabular}{|c|c|c|c|c|c|c|c|c|c|c|c|}
\hline \multicolumn{12}{|c|}{ Superficial Layers (0-30 cm Soil Depth) } \\
\hline \multicolumn{2}{|l|}{ Soil classification } & $\mathrm{pH}$ & $\mathrm{CaCO}_{3}$ & Sand & Silt & Clay & TOC & FC & $\mathrm{BD}$ & $\mathrm{EC}_{\mathrm{ew}}$ & $\mathrm{EC}_{\mathrm{es}}$ \\
\hline & & & \multicolumn{6}{|c|}{$\%$} & $\mathrm{~g} \mathrm{~cm}^{-3}$ & \multicolumn{2}{|c|}{$\mathrm{dS} \mathrm{m}^{-1}$} \\
\hline \multirow{2}{*}{ euAR } & mean & 7.5 & 11.4 & 90 & 6 & 4 & 0.3 & 18 & 1.5 & 1.5 & 0.9 \\
\hline & SE & 0.1 & 1.8 & 2.9 & 1.8 & 1.6 & 0.3 & 4.0 & 0.1 & 0.4 & 0.2 \\
\hline \multirow{2}{*}{ fvCM } & mean & 7.8 & 16.9 & 33 & 49 & 18 & 0.8 & 23 & 1.5 & 1.1 & 1.5 \\
\hline & SE & 0.1 & 4.2 & 2.5 & 2.7 & 0.6 & 0.2 & 1.9 & 0.1 & 0.1 & 0.3 \\
\hline \multirow{2}{*}{$\mathrm{glCM}$} & mean & 7.8 & 19.6 & 20 & 59 & 21 & 0.8 & 27 & 1.5 & 1.6 & 1.2 \\
\hline & SE & 0.1 & 1 & 4.4 & 2.9 & 1.8 & 0.1 & 2.4 & 0 & 0.4 & 0.3 \\
\hline \multirow{2}{*}{$\mathrm{gl}(\mathrm{s}) \mathrm{CM}$} & mean & 7.8 & 19.3 & 15 & 51 & 34 & 0.7 & 26 & 1.5 & 1.6 & 2.5 \\
\hline & $\mathrm{SE}$ & 0.1 & 1 & 3.2 & 4.7 & 4.7 & 0.1 & 2.0 & 0.1 & 0.2 & 0.3 \\
\hline \multirow{2}{*}{ stCM } & mean & 7.8 & 20.8 & 7 & 49 & 44 & 1.1 & 29 & 1.9 & 1.7 & 2.1 \\
\hline & SE & 0.1 & 1.8 & 0.8 & 4.2 & 3.7 & 0.2 & 1.7 & 0 & 0.4 & 0 \\
\hline \multirow{2}{*}{ vr/glCM } & mean & 7.9 & 17.1 & 14 & 48 & 38 & 1.1 & 23 & 1.7 & 1.2 & 1.6 \\
\hline & SE & 0.0 & 1.1 & 2.7 & 2.2 & 1.9 & 0.1 & 1.6 & 0.1 & 0.2 & 0.1 \\
\hline \multicolumn{12}{|c|}{ Depth Layers (30-90 cm Soil Depth) } \\
\hline \multirow[t]{2}{*}{ Soil classification } & & $\mathrm{pH}$ & $\mathrm{CaCO}_{3}$ & Sand & Silt & Clay & TOC & $\mathrm{FC}$ & $\mathrm{BD}$ & $\mathrm{EC}_{\mathrm{ew}}$ & $\mathrm{EC}_{\mathrm{es}}$ \\
\hline & & & \multicolumn{6}{|c|}{$\%$} & $\mathrm{~g} \mathrm{~cm}^{-3}$ & \multicolumn{2}{|c|}{$\mathrm{dS} \mathrm{m}^{-1}$} \\
\hline \multirow{2}{*}{ euAR } & mean & 7.5 & 11.4 & 90 & 6 & 4 & 0.3 & 18 & 1.5 & 1.5 & 0.8 \\
\hline & SE & 0.1 & 1.8 & 2.9 & 1.8 & 1.6 & 0.3 & 4 & 0.1 & 0.4 & 0.2 \\
\hline \multirow{2}{*}{$\mathrm{fvCM}$} & mean & 7.8 & 16.9 & 33 & 49 & 18 & 0.8 & 23 & 1.5 & 1.5 & 1.5 \\
\hline & SE & 0.1 & 4.2 & 2.5 & 2.7 & 0.6 & 0.2 & 1.9 & 0.1 & 0.1 & 0.3 \\
\hline \multirow{2}{*}{$\mathrm{glCM}$} & mean & 7.8 & 19.6 & 21 & 59 & 20 & 0.8 & 27 & 1.9 & 1.5 & 1.2 \\
\hline & SE & 0.0 & 1 & 4.4 & 2.9 & 1.8 & 0.1 & 2.4 & 0 & 0.4 & 0.3 \\
\hline \multirow{2}{*}{$\mathrm{gl}(\mathrm{s}) \mathrm{CM}$} & mean & 7.8 & 19.3 & 15 & 51 & 34 & 0.7 & 26 & 1.5 & 1.9 & 2.5 \\
\hline & SE & 0.0 & 1 & 3.2 & 4.7 & 4.7 & 0.1 & 2 & 0.1 & 0.2 & 0.3 \\
\hline \multirow{2}{*}{ stCM } & mean & 7.8 & 20.8 & 7 & 53 & 40 & 1.1 & 29 & 1.6 & 1.6 & 2.1 \\
\hline & SE & 0.1 & 1.8 & 0.8 & 4.2 & 3.7 & 0.2 & 1.7 & 0 & 0.4 & 0 \\
\hline \multirow{2}{*}{$\mathrm{vr} / \mathrm{glCM}$} & mean & 7.9 & 16.9 & 19 & 45 & 36 & 1.1 & 23 & 1.7 & 1.7 & 1.6 \\
\hline & SE & 0.1 & 1.1 & 2.7 & 2.2 & 1.9 & 0.1 & 1.6 & 0.1 & 0.2 & 0.1 \\
\hline
\end{tabular}

euAR = Eutric Arenosols; fvCM = Fluvic Cambisols; glCM = Gleyic Cambisols; gl(s)CM = Endogleyic Cambisols; stCM = Stagnic Cambisols; vr/glCM = Vertic and Gleyic Cambisols.

Within the Cambisol reference group, for both layers there were few differences among the soils. In particular, the glCM showed the highest values of silt and BD, while the stCM had the highest values of carbonate and water content at field capacity and the lowest amount of sand. Although for both soil layers of Cambisols the TOC content was generally higher compared to Arenosols, the amounts of organic $\mathrm{C}$ were always lower than $1.5 \%$.

The $\mathrm{EC}_{\mathrm{ew}}$ values in the superficial layer (SL) ranged between 1.1 and $1.7 \mathrm{dS} \mathrm{m} \mathrm{m}^{-1}$ and did not significantly differ among soil types; in the deeper layer (DL), the $\mathrm{EC}_{\mathrm{ew}}$ values ranged between 1.5 and $1.9 \mathrm{dS} \mathrm{m} \mathrm{m}^{-1}$ and the highest values were found in $\mathrm{gl}(\mathrm{s}) \mathrm{CM}$. In summer for both layers, a larger range of $\mathrm{EC}_{\mathrm{es}}$ values was detected, $0.9-2.5 \mathrm{dS} \mathrm{m}^{-1}$ and $0.8-2.5 \mathrm{dS} \mathrm{m}^{-1}$ in SL and DL, respectively, with the lowest $\mathrm{EC}_{\mathrm{es}}$ values observed in euAR and glCM, while the highest ones were in gl(s)CM soil type. 
Table 3 shows the correlation matrix among physicochemical properties of investigated soils. Positive correlations were found between clay and organic $\mathrm{C}$ content, and between clay and both water content at field capacity and EC detected in summer.

Table 3. Correlation matrix among $\mathrm{pH}$, amounts of carbonates $\left(\mathrm{CaCO}_{3}\right)$, clay and total organic $\mathrm{C}$ (TOC), water content at field capacity (FC), bulk density (BD) and electrical conductivity in the non-irrigation winter period $\left(\mathrm{EC}_{\mathrm{ew}}\right)$ and irrigation summer period $\left(\mathrm{EC}_{\mathrm{es}}\right) .{ }^{*}$ indicates significant Spearman's rank correlation coefficients $(p<0.05)$.

\begin{tabular}{ccccccccc}
\hline Soil Properties & $\mathrm{pH}$ & $\mathrm{CaCO}_{3}$ & Clay & TOC & FC & BD & EC $_{\text {ew }}$ & EC $_{\text {es }}$ \\
\hline $\mathrm{pH}$ & 1.00 & & & & & & & \\
$\mathrm{CaCO}_{3}$ & 0.21 & 1.00 & & & & & & \\
$\mathrm{Clay}$ & 0.21 & $0.40 *$ & 1.00 & & & & & \\
$\mathrm{TOC}$ & 0.11 & $0.43 *$ & $0.56^{*}$ & 1.00 & & & & \\
$\mathrm{FC}$ & 0.00 & 0.31 & $0.48^{*}$ & 0.32 & 1.00 & & & \\
$\mathrm{BD}$ & 0.15 & -0.06 & 0.06 & 0.18 & -0.06 & 1.00 & & \\
$\mathrm{EC}$ & -0.01 & -0.03 & 0.01 & -0.10 & 0.11 & -0.01 & 1.00 & \\
$\mathrm{EC}_{\mathrm{es}}$ & 0.01 & $0.50 *$ & $0.56^{*}$ & 0.25 & 0.27 & -0.14 & 0.01 & 1.00 \\
\hline
\end{tabular}

\subsection{Water Quality of Canals Network and Water Bodies in Agricultural Coastal Plain}

The statistical summary of physicochemical parameters of water quality collected in the winter and summer periods is shown in Table S2 in Supplementary Materials. Generally, much data variability was observed. In summer, high loads of nutrients and contaminants were detected (i.e., TN, BOD and $\mathrm{SO}_{4}{ }^{2-}$; Table S2), worsening the water quality.

Among the water body types, the winter period showed no relevant significant differences, with the exception of lower EC values in FW and WE (Figure 4).

In contrast, all parameters showed significant differences in the summer season. High degradation of water quality and an increase of nutrients was detected in the FWv stations (SAR, 133; EC, $24.5 \mathrm{dS} \mathrm{m}^{-1}$; $\mathrm{Cl}^{-}, 1604 \mathrm{mg} \mathrm{L}^{-1} ; \mathrm{SO}_{4}{ }^{2-}$, $792 \mathrm{mg} \mathrm{L}^{-1}$; COD, $326 \mathrm{mg} \mathrm{L}^{-1}$; $\mathrm{BOD}, 208 \mathrm{mg} \mathrm{L}^{-1}$ ), followed by W stations. It is interesting to observe that in the minor drainage network of canals (MiDC), a high concentration of both nutrients (14.4 $\mathrm{mg} \mathrm{L}^{-1}$ for TN) and organic matter (240 and $130 \mathrm{mg} \mathrm{L}^{-1}$ for COD and BOD, respectively) was determined. This behavior was observed also for the main drainage canals (MaDC), while in the promiscuous canals network (PC), mainly used for irrigation, the nutrients load was lower than the MaDC and MiDC network. Finally, low nutrients load and EC were detected in constructed wetlands (WE) present in the agricultural land and isolated from the hydrographic network.

\subsection{Spatial Distribution of Soil and Water Salinity in the Agricultural Coastal Plain}

In summer, the linear model between EC and soil classification showed that only the average value of glsCM statistically differed among other soils $(p=0.003)$, this behavior is true also for the winter season in the deeper layers (data not shown). For water samples, the linear model of logEC showed that the sites near the coast (FWv) and wells (W) were significantly higher than the others $(p=0.001$; data not shown). In order to evaluate if a spatial correlation was present, the residual values, obtained from the models for soil and water, were also estimated, building a variogram as provisional map. Figure 5 shows the variogram both for the $0-30 \mathrm{~cm}$ soil depth (Figure 5a,c) and for the water monitoring points (Figure $5 \mathrm{~b}, \mathrm{~d}$ ) during the non-irrigation winter period and the summer period.

In winter, the variogram confirmed a certain salt homogeneity in the soils of the area (Figure 5a), without spatial correlation among the soils. In summer, the pattern of spatial distribution of EC values in the superficial soil layer greatly changed with respect to the winter period. However, the soils most affected by high salinity were again glCM and gl(s)CM (Figure 5c). During the winter period, saline intrusion from the sea into watercourses appeared evident from the variogram, indicating a gradient from coastal areas toward the inland (Figure 5b). It is interesting to notice the 
mitigation of EC values during the summer period with respect to the winter (Figure $5 b, d)$. The decrease of EC was due to introduction of fresh water in the canal network for irrigation purposes.
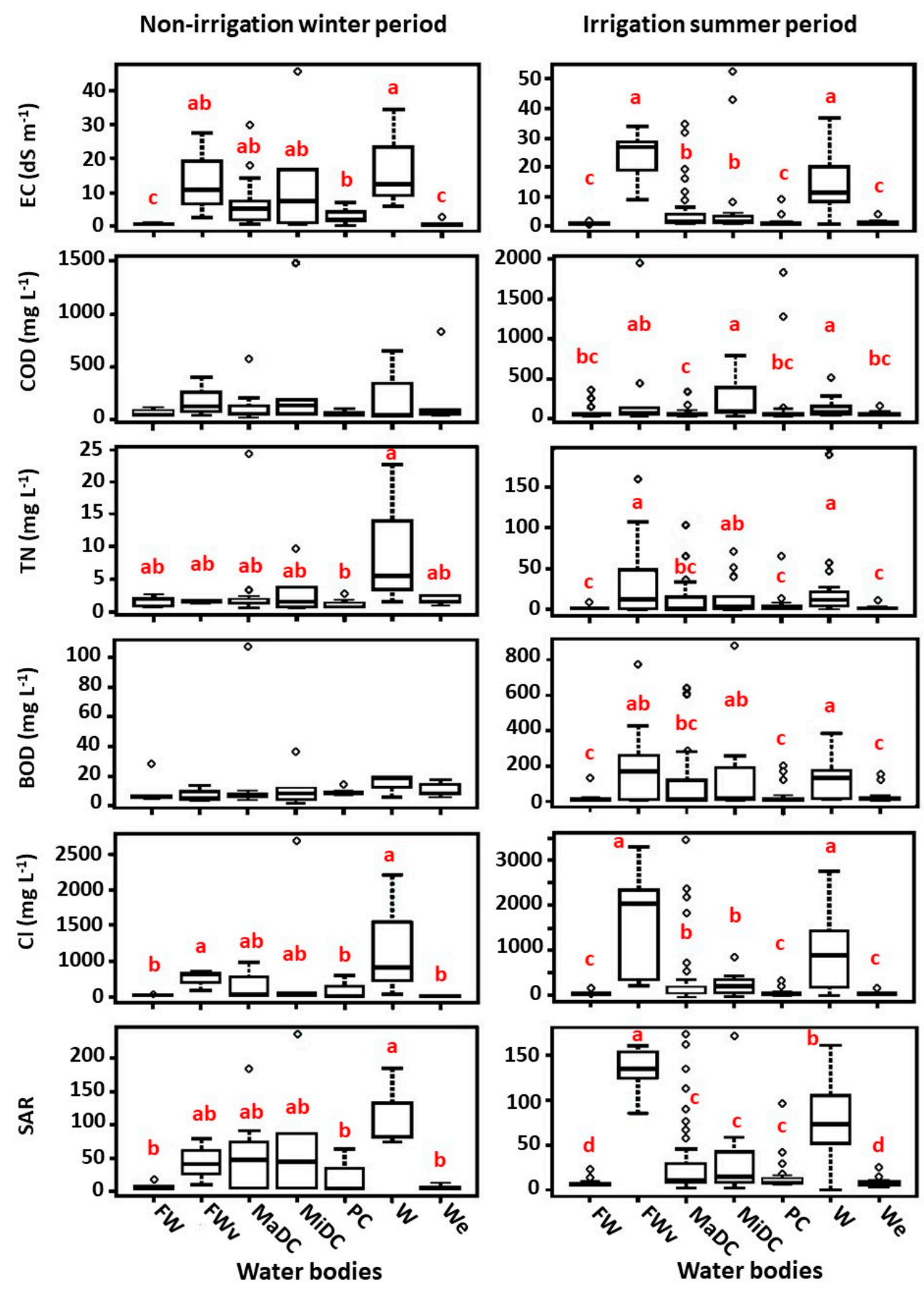

Figure 4. Electrical conductivity (EC), chemical oxygen demand (COD), total $\mathrm{N}$ content (TN), biological oxygen demand (BOD), $\mathrm{Cl}$ content $(\mathrm{Cl})$, and sodium absorption ratio (SAR) in water samples collected in the non-irrigation winter period and irrigation summer period from upstream and downstream stations on the Reno river, Lamone river and Right Reno river canal (FW and FWv, respectively), drainage canal (MaDC), drainage and irrigation canal (MiDC), drainage and irrigation canal (PC), wetland landlocked inside the agricultural land (W), and well at $3 \mathrm{~m}$ depth (WE). Different letters indicate significant differences $(p<0.05)$. In order to better show the differences for each parameter among the water bodies, a different $y$-axis scale was used for the non-irrigation winter period and for the irrigation summer period. 
a
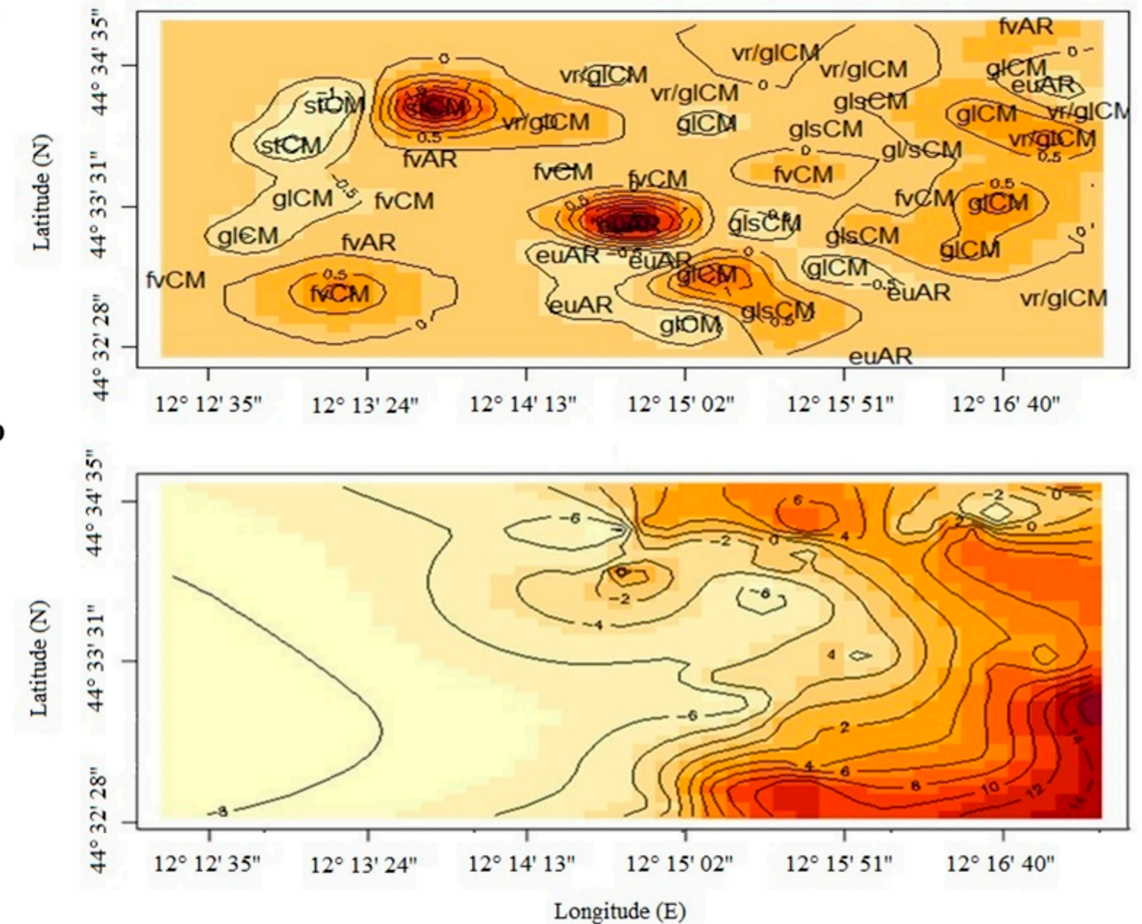
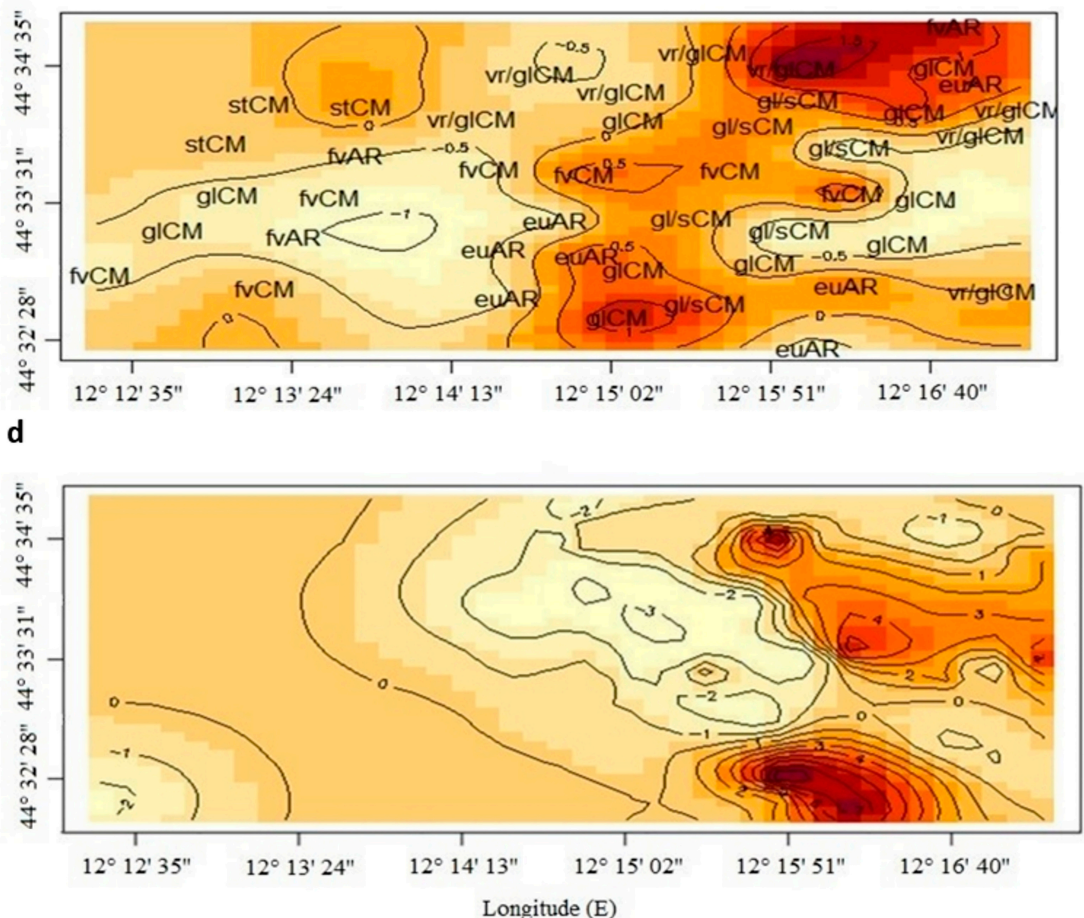

Figure 5. Variogram of residual values of the linear model for the (a) 0-30 cm soil depth and (b) water body network during the non-irrigation winter period, and for the (c) $0-30 \mathrm{~cm}$ soil depth and (d) water body network during the irrigation summer period. 


\section{Discussion}

\subsection{Organic C Concentration and Seasonal Evolution of Soil Salinity}

The accumulation of salts in soils is well recognized to have adverse effect on soil organic $\mathrm{C}$ contents [35,36]. Our study confirmed the shortage of organic $C$ in the investigated salt-affected soils. In particular, the TOC concentration in the investigated area was on average always lower than $2 \%$ (Table 2), which is considered the threshold for soil health [30]. In fact, when the TOC contents reach values below $2 \%$, potentially serious degradation of the soil quality could occur [37], and thus the already low soil function capacity (e.g., biomass and food production, maintaining soil biodiversity, carbon and nutrient sequestration, water filtration) could be further compromised due to the high organic $C$ leaching that characterizes the sandy soils [38]. The low TOC content was observed in all soil types, showing therefore a widespread vulnerability to degradation of the investigated soils. Since lower TOC content was detected in Arenosols than in Cambisols, our findings might suggest higher vulnerability of the Arenosols to the organic matter loss and, therefore, to soil quality degradation. The different TOC concentrations should be due to the different particle size distribution typical of these soils, as suggested by the positive correlation between TOC and clay content. Clay surface provides the major mineral surface in temperate soils that effectively stabilizes soil organic $C$, by decreasing $C$ turnover rates $[39,40]$. Therefore, we suppose that clay scarcity, typical of Arenosols, is the reason for their low capacity of $C$ storage. This is in agreement with Don et al. [41] who observed that in Arenosols the soil organic $\mathrm{C}$ accumulation was limited by low total clay surface available for $\mathrm{C}$ stabilization. However, our Cambisols should be vulnerable to water stagnation due to their high $B D$ (generally $\geq 1.5 \mathrm{~g} \mathrm{~cm}^{-3}$ ), which reduces water infiltration and slows internal drainage [42]. This poor physical soil quality, worsened by the low TOC content [43], can increase the risk of soil waterlogging, soil anoxia and obstruction of root growth [44,45], and limits salt leaching [46].

Related to soil degradation, the $\mathrm{EC}_{\mathrm{e}}$ has been used to measure soil salinity since $1950 \mathrm{~s}[47,48]$ and can be used as proxy to describe soil salinization. The behavior of salinity in soils is mainly influenced by texture class, as evidenced by the high positive correlation between the summer EC and the clay content (Table 3), making the soils on fine texture deposits (silty clay, clays and peat deposits) vulnerable to salinization. The observed soil seasonal salinity seemed to be in contrast to Genua-Olmedo et al. [49] who found low salinity values in Ebro Delta clay soils. They in fact stated that sandy soils, located at lower elevation than clay soils, tended to be permeable and, therefore, rapidly allowed salt intrusion from underground water and increase of soil salinity in the root zone. In our investigated area, instead, finer texture soils, having high water field capacity, strongly retained salt waters and increased their EC values. In fact, while the EC of Arenosols declined from the winter to summer season, in Cambisols the EC values did not change over time (Table 2, Figure 5a,c). Additionally, if we take into account that the investigated winter season was wetter than the typical one (see mean precipitation data reported in the Materials and Methods section), it further stressed the high salt retention of the studied Cambisols.

\subsection{Seasonal Evolution of Water Quality}

In winter season about $80 \%$ of the investigated water bodies had water EC $>4 \mathrm{dS} \mathrm{m}^{-1}$ (Figure 4), confirming the low quality of water in both rivers and the artificial canal network [14] and the diffuse saline intrusion in the study area [12]. The low water quality leads to a high risk of sodium and salt accumulation in the soil.

As evident from Figure $5 b$,d the saline intrusion from sea into watercourses greatly increased the EC in the water bodies near the coast. However, in the summer period (i.e., within the irrigation period; Figure 5d), the effect of the seawater intrusion was counteracted by the introduction of fresh water inside the irrigation canals. As a consequence of the lowering of the water EC, the risk of soil salinization in superficial soil layers decreased. Therefore, we suppose that, during the entire year, the risk of soil salinization was mainly due to the effect of groundwater salinity and to the different upcoming phenomena of saline water. 
Our data (Figure 4) further showed that in the summer season, an increase of water eutrophication with an increased load of both nutrients and contaminants occurred, as shown by the higher values of TN, BOD and sulfates [14]. The increase of these values could be due to the high concentration of dissolved organic matter leached from soil [50,51], probably caused by the large input of water for irrigation. This hypothesis is further supported by the high increase of TN and organic matter in drainage channels (MiDC and MaDC). Finally, the SAR value of water indicated a high risk of soil alkalization, with damage to soil structure and consequential loss of soil organic matter.

\subsection{Risk of Soil Degradation Due to Soil Type-Irrigation Water Interaction}

The soil system in the investigated area appeared extremely fragile, due to paucity of organic $C$ content and high BD (Table 2). In fact, the soil quality, and therefore the capacity of soil to minimize the effect of indiscriminate soil management, is often related to TOC and BD values [52]. Concerning the degradation risk related to salinization, our findings suggest a high upcoming of salt groundwater. This enhanced an environmental pressure to an already vulnerable soil system, increasing the risk of soil salinization. The soil EC seasonal fluctuations show that the high risk of soil salinization could be at least partially reduced by soil irrigation with high water quality (Figures 4 and $5 b, d$ ).

However, some doubts still remain about the long-term efficacy of soil desalination by high water quality use. In fact, as reported in the present study, only the superficial layer of the coarser texture soils (Arenosols) appeared to allow salt removal, while finer texture soils did not efficaciously reduce their EC values (Table 2, Figure 5a,c). Our findings are in agreement with those of Masina et al. [53] who simulated the impact of different salt mitigation practices in Cambisols located in our study area. In particular, to control the salinization in superficial soil layers, the authors highlighted the poor suitability of salt leaching and suggested the use of flooded pipe drains to prevent salt rising from brackish groundwater. This practice would also limit the leaching of nutrients from soil to water bodies.

\section{Conclusions}

In the present work, TOC content, BD and ECe values allowed us to highlight the vulnerability of the soils studied, which appear well-related to soil types. In particular, the soils are subjected to sea saline intrusion, which worsens their health, and human activity acts as a powerful soil quality factor by regulating water flow in soil by artificial water drainage and soil irrigation. Given the site-specificity of the soil vulnerability to salinization, water management should be accurately revised. In fact, the current use of the water resource has a limited positive effect on the counteraction of soil salinization, being effective only on Arenosols, and increases the risk of organic matter loss from the already degraded soils. Other practices for the control of soil salinization should be envisaged, such as the use of flooded pipe drains to prevent salt rising from brackish groundwater.

Our data can help to provide a better understanding of how soils will be impacted by salts leaching in coastal areas affected by both water irrigation management and seawater intrusion, being useful for farmers and decision makers to support decisions for soil protection. We show that it is necessary to take in account soil types and properties to limit the negative effects caused by irrigation itself. Knowledge and monitoring of soil and water properties are a helpful tool for detecting the most suitable strategies to control the soil salinization.

Supplementary Materials: The following are available online at http://www.mdpi.com/2075-163X/10/4/369/s1. The supplemental material includes Supplemental Table S1 and Table S2. The former shows the results of the Kruskall-Wallis test on $\mathrm{pH}$, amounts of total organic $\mathrm{C}(\mathrm{TOC})$, carbonates $\left(\mathrm{CaCO}_{3}\right)$, sand, silt and clay, water content at field capacity (FC), bulk density (BD), soil electrical conductivity in the non-irrigation winter period (ECew) and in the irrigation summer period (ECes) for superficial and deep layers, according to soil classification. The supplemental Table S2 shows the statistical summary of $\mathrm{pH}$, electrical conductivity (EC), total N (TN), biological demand of oxygen (BOD), chemical demand of oxygen (COD), total P (TP), sulfates, chlorides and sodium adsorption ratio (SAR) of water samples collected during the non-irrigation winter period and the irrigation summer period. 
Author Contributions: Formal analysis, L.V.A.; Funding acquisition, M.S.; Investigation, C.F., M.D.F. and G.V.; Methodology, L.V.A. and G.F.; Supervision, G.F.; Writing-original draft, L.V.A., M.D.F. and G.F.; Writing-review and editing, L.V.A., M.S., M.D.F., G.V. and G.F. All authors have read and agreed to the published version of the manuscript.

Funding: This study was financed by the LIFE 2014-2020 Programme, through the LIFE AGROWETLANDS II-Smart Water and Soil Salinity Management in AgroWetlands (LIFE15 ENV/IT/000423) Project.

Conflicts of Interest: The authors declare no conflict of interest.

\section{References}

1. Daliakopoulos, I.N.; Tsanis, I.K.; Koutroulis, A.; Kourgialas, N.N.; Varouchakis, A.E.; Karatzas, G.P.; Ritsema, C.J. The threat of soil salinity: A European scale review. Sci. Total Environ. 2016, 573, 727-739. [CrossRef] [PubMed]

2. FAO. Status of the World's Soil Resources; Intergovernmental Technical Panel on Soils: Rome, Italy, 2015; pp. 123-126.

3. Tóth, G.; Montanarella, L.; Rusco, E. Threats to Soil Quality in Europe; Institute for Environment and Sustainability: Ispra, Italy, 2008.

4. Bauder, J.W.; Brock, T.A. Irrigation Water Quality, Soil Amendment, and Crop Effects on Sodium Leaching. Arid Land Res. Manag. 2001, 15, 101-113. [CrossRef]

5. Barbarella, M.; Giglio, M.D.; Avantaggiato, A. Studio degli effetti dell'intrusione del cuneo salino sulla vegetazione costiera mediante dati satellitari. In Proceedings of the Atti 16a Conferenza Nazionale ASITA, Vicenza, Italy, 6-8 November 2012; pp. 121-128.

6. Andreu, L.; Moreno, F.; Jarvis, N.J.; Vachaud, G. Application of the model MACRO to water movement and salt leaching in drained and irrigated marsh soils, Marismas, Spain. Agric. Water Manag. 1994, 25, 71-88. [CrossRef]

7. Ayers, R.S.; Westcot, D.W. Water Quality for Agriculture; FAO United Nations: Rome, Italy, 1985 ; p. 97.

8. Artiola, J.F.; Walworth, J.L. Irrigation water quality effects on soil carbon fractionation and organic carbon dissolution and leaching in a semiarid calcareous soil. Soil Sci. 2009, 174, 365-371. [CrossRef]

9. Minhas, P.S.; Ramos, T.B.; Ben-Gal, A.; Pereira, L.S. Coping with salinity in irrigated agriculture: Crop evapotranspiration and water management issues. Agric. Water Manag. 2020, 227, 105832. [CrossRef]

10. Mateo-sagasta, J. Agriculture and Water Quality Interactions: A Global Overview; FAO: Rome, Italy, 2010; Volume 8, pp. 25-34.

11. Panagea, I.S.; Daliakopoulos, I.N.; Tsanis, I.K.; Schwilch, G. Evaluation of promising technologies for soil salinity amelioration in Timpaki (Crete): A participatory approach. Solid Earth 2016, 7, 177-190. [CrossRef]

12. Buscaroli, A.; Zannoni, D. Influence of ground water on soil salinity in the San Vitale Pinewood (Ravenna-Italy). Agrochimica 2010, 5, 303-320.

13. Teatini, P.; Ferronato, M.; Gambolati, G.; Bertoni, W.; Gonella, M. A century of land subsidence in Ravenna, Italy. Environ. Geol. 2005, 47, 831-846. [CrossRef]

14. Petrini, R.; Pennisi, M.; Vittori Antisari, L.; Cidu, R.; Vianello, G.; Aviani, U. Geochemistry and stable isotope composition of surface waters from the Ravenna plain (Italy): Implications for the management of water resources in agricultural lands. Environ. Earth Sci. 2014, 71, 5099-5111. [CrossRef]

15. RER Carta dei suoli dell'Emilia Romagna. Available online: https://ambiente.regione.emilia-romagna.it/it/ geologia/suoli (accessed on 19 May 2017).

16. Antonellini, M.; Mollema, P.N.; Capo, D.; Greggio, N.; Allen, D.M. Groundwater freshening following coastal progradation and land reclamation of the Po Plain, Italy. Hydrogeol. J. 2015, 23, 1009-1026. [CrossRef]

17. Western Romagna Land Reclamation Consortium. Available online: https://www.romagnaoccidentale.it/\# (accessed on 11 April 2020).

18. Zucaro, R.; Furlani, A. Rapporto sullo stato dell'irrigazione in Emilia-Romagna; INEA: Rome, Italy, 2009.

19. ISPRA CARG Project-Geological and Geothematic Cartography. Available online: www.isprambiente.gov.it/en/ projects/soil-and-territory/carg-project-geologic-and-geothematic-cartography (accessed on 19 May 2017).

20. FAO. World Reference Base for Soil Resources 2014: International Soil Classification System for Naming Soils and Creating Legends for Soil Maps; FAO: Rome, Italy, 2014. 
21. Cipolla, S.S.; Maglionico, M.; Serra, F.; Venturi, M. Modellazione Numerica Per La Gestione Dei Canali Di Bonifica Del Comparto Idraulico Savarna- Sant' Alberto-Mandriole (Ravenna). In Proceedings of the Atti del XXXVI Convegno Nazionale di Idraulica e Costruzioni Idrauliche, Ancona, Italy, 12-14 September 2018; pp. 12-14.

22. Cipolla, S.S.; Maglionico, M.; Masina, M.; Lamberti, A.; Daprà, I. Real time monitoring of water quality in an agricultural area with salinity problems. Environ. Eng. Manag. J. 2019, 18, 2229-2240.

23. Wibawa, W.D.; Dludlu, D.L.; Swenson, L.J.; Hopkins, D.G.; Dahnke, W.C. Variable Fertilizer Application Based on Yield Goal, Soil Fertility, and Soil Map Unit. JPA 1993, 6, 255. [CrossRef]

24. ARPAE Osservatorio Clima Emilia-Romagna, Agenzia Prevenzione Ambiente Energia Emilia Romagna. Available online: https://www.arpae.it/dettaglio_generale.asp?id=2867\&idlivello=1591 (accessed on 9 April 2020).

25. Pan, W.; Boyles, R.P.; White, J.G.; Heitman, J.L. Characterizing soil physical properties for soil moisture monitoring with the North Carolina environment and climate observing network. J. Atmos. Ocean. Technol. 2012, 29, 933-943. [CrossRef]

26. Klute, A. Water Retention: Laboratory Methods. In Methods of Soil Analysis: Part 1-Physical and Mineralogical Methods; SSSA Book Series: Madison, WI, USA, 1986.

27. Schulte, E.E.; Hopkins, B.G. Estimation of organic matter by weight loss-on-ignition. Soil Org. Matter Anal. Interpret. 1996, 46, 21-31.

28. Cambardella, C.A.; Gajda, A.M.; Doran, J.W.; Wienhold, B.J.; Kettler, T.A. Estimation of particulate and total organic matter by weight loss-on-ignition. In Assessment Methods for Soil Carbon (Advances in Soil Science); CRC Press: Boca Raton, FL, USA, 2001; pp. 349-359.

29. Howard, P.J.A.; Howard, D.M. Use of organic carbon and loss-on-ignition to estimate soil organic matter in different soil types and horizons. Biol. Fertil. Soils 1990, 9, 306-310. [CrossRef]

30. Abella, S.R.; Zimmer, B.W. Estimating Organic Carbon from Loss-On-Ignition in Northern Arizona Forest Soils. Soil Sci. Soc. Am. J. 2007, 71, 545. [CrossRef]

31. De Vos, B.; Vandecasteele, B.; Deckers, J.; Muys, B. Capability of loss-on-ignition as a predictor of total organic carbon in non-calcareous forest soils. Commun. Soil Sci. Plant Anal. 2005, 36, 2899-2921. [CrossRef]

32. Loeppert, R.H.; Suarez, D.L. Carbonate and Gypsun; USDA-ARS/UNL Faculty: Lincoln, CA, USA, 1996.

33. Gee, G.W.; Bauder, J.W. Methods of Soil Analysis: Part 1—Physical and Mineralogical Methods; SSSA Book Series; Soil Science Society of America, American Society of Agronomy: Madison, WI, USA, 1986.

34. R Core Team. R: A Language and Environment for Statistical Computing; R Foundation for Statistical Computing: Vienna, Austria, 2014.

35. Setia, R.; Gottschalk, P.; Smith, P.; Marschner, P.; Baldock, J.; Setia, D.; Smith, J. Soil salinity decreases global soil organic carbon stocks. Sci. Total Environ. 2013, 465, 267-272. [CrossRef]

36. Nabiollahi, K.; Taghizadeh-Mehrjardi, R.; Kerry, R.; Moradian, S. Assessment of soil quality indices for salt-affected agricultural land in Kurdistan Province, Iran. Ecol. Indic. 2017, 83, 482-494. [CrossRef]

37. Loveland, P.; Webb, J. Is there a critical level of organic matter in the agricultural soils of temperate regions: A review. Soil Tillage Res. 2003, 70,1-18. [CrossRef]

38. Vinther, F.P.; Hansen, E.M.; Eriksen, J. Leaching of soil organic carbon and nitrogen in sandy soils after cultivating grass-clover swards. Biol. Fertil. Soils 2006, 43, 12-19. [CrossRef]

39. Swanston, C.W.; Torn, M.S.; Hanson, P.J.; Southon, J.R.; Garten, C.T.; Hanlon, E.M.; Ganio, L. Initial characterization of processes of soil carbon stabilization using forest stand-level radiocarbon enrichment. Geoderma 2005, 128, 52-62. [CrossRef]

40. Lutzow, M.V.; Kogel-Knabner, I.; Ekschmitt, K.; Matzner, E.; Guggenberger, G.; Marschner, B.; Flessa, H. Stabilization of organic matter in temperate soils: Mechanisms and their relevance under different soil conditions-A review. Eur. J. Soil Sci. 2006, 57, 426-445. [CrossRef]

41. Don, A.; Scholten, T.; Schulze, E.-D. Conversion of cropland into grassland: Implications for soil organic-carbon stocks in two soils with different texture. J. Plant Nutr. Soil Sci. 2009, 172, 53-62. [CrossRef]

42. Benbi, D.K.; Nieder, R. Handbook of Processes and Modeling in the Soil-Plant System; CRC Press: New York, NY, USA, 2003.

43. Celik, I. Land-use effects on organic matter and physical properties of soil in a southern Mediterranean highland of Turkey. Soil Tillage Res. 2005, 83, 270-277. [CrossRef]

44. Morrissey, E.M.; Gillespie, J.L.; Morina, J.C.; Franklin, R.B. Salinity affects microbial activity and soil organic matter content in tidal wetlands. Glob. Chang. Biol. 2014, 20, 1351-1362. [CrossRef] 
45. Rietl, A.J.; Overlander, M.E.; Nyman, A.J.; Jackson, C.R. Microbial Community Composition and Extracellular Enzyme Activities Associated with Juncus roemerianus and Spartina alterniflora Vegetated Sediments in Louisiana Saltmarshes. Microb. Ecol. 2016, 71, 290-303. [CrossRef]

46. Shaygan, M.; Baumgartl, T.; Arnold, S.; Reading, L.P. The effect of soil physical amendments on reclamation of a saline-sodic soil: Simulation of salt leaching using HYDRUS-1D. Soil Res. 2018, 56, 829-845. [CrossRef]

47. Richards, L.A. Diagnosis and Improvement of Saline and Alkali Soils; United States Department of Agriculture: Washington, DC, USA, 1954; Volume 78.

48. Sparks, D.L.; Page, A.L.; Helmke, P.A.; Loeppert, R.H.; Rhoades, J.D. Salinity: Electrical Conductivity and Total Dissolved Solids. In Methods of Soil Analysis Part 3-Chemical Methods; Soil Science Society of America and American Society of Agronomy: Madison, WI, USA, 1996.

49. Genua-Olmedo, A.; Alcaraz, C.; Caiola, N.; Ibáñez, C. Sea level rise impacts on rice production: The Ebro Delta as an example. Sci. Total Environ. 2016, 571, 1200-1210. [CrossRef]

50. He, Y.; Lehndorff, E.; Amelung, W.; Wassmann, R.; Alberto, M.C.; von Unold, G.; Siemens, J. Drainage and leaching losses of nitrogen and dissolved organic carbon after introducing maize into a continuous paddy-rice crop rotation. Agric. Ecosyst. Environ. 2017, 249, 91-100. [CrossRef]

51. Said-Pullicino, D.; Miniotti, E.F.; Sodano, M.; Bertora, C.; Lerda, C.; Chiaradia, E.A.; Romani, M.; Cesari de Maria, S.; Sacco, D.; Celi, L. Linking dissolved organic carbon cycling to organic carbon fluxes in rice paddies under different water management practices. Plant Soil 2016, 401, 273-290. [CrossRef]

52. De Paul Obade, V.; Lal, R. Towards a standard technique for soil quality assessment. Geoderma 2016, 265, 96-102. [CrossRef]

53. Masina, M.; Calone, R.; Barbanti, L.; Mazzotti, C.; Lamberti, A.; Speranza, M. Smart water and soil salinity management in agro-wetlands. Environ. Eng. Manag. J. 2019, 2273-2285.

(C) 2020 by the authors. Licensee MDPI, Basel, Switzerland. This article is an open access article distributed under the terms and conditions of the Creative Commons Attribution (CC BY) license (http://creativecommons.org/licenses/by/4.0/). 